Original Research Article

\title{
Knowledge, attitude and practices of generic names usage in prescription among the medical postgraduate residents of a tertiary care teaching hospital: an observational cross-sectional study
}

\author{
Rakesh R. Jadhav, Rushikesh S. Kulkarni*, Arati V. Rathod
}

Department of Pharmacology, Swami Ramanand Teerth Government Rural Medical College, Ambajogai, Maharashtra, India

Received: 28 February 2019 Accepted: 30 March 2019

\section{*Correspondence to:}

Dr. Rushikesh S. Kulkarni, Email: rushikeshk3@gmail.com

Copyright: (C) the author(s), publisher and licensee Medip Academy. This is an openaccess article distributed under the terms of the Creative Commons Attribution NonCommercial License, which permits unrestricted noncommercial use, distribution, and reproduction in any medium, provided the original work is properly cited.

\begin{abstract}
Background: Establishment of Pradhan Mantri Bhartiya Janaushadhi Kendras through Pradhan Mantri Janaushadhi Pariyojana (PMBJP) is a breakthrough step to reduce expenses in healthcare due to costly branded names in prescription. Medical council of India also amended clause 1.5 of the Indian Medical Council Regulations, 2002 mandating the doctors to prescribe medicines by generic names in place of brand names. Moreover, medical practitioner nowadays has raised concern about education/qualification of the chemist who is being made the decision maker.

Methods: In this questionnaire based cross-sectional observational study, all students admitted to post graduation course in academic year 2018 were included and those who were not willing to give consent were excluded from study. A knowledge, attitude and practices (KAP) questionnaire containing 12 questions was assessed by using true/false type and Likert scale-based questions. Descriptive statistics used to generate frequencies, percentages and proportions. Results: Majority of the population have answered positively about knowledge questions. Surprisingly $72.41 \%$ population don't know about process of new drug approval. Most of them agreed to pros and cons of generic drug prescribing. $58.14 \%$ population always write generic names in their prescription. Shockingly $74.42 \%$ population write prescription based on their knowledge from promotional literature by a medical representative.

Conclusions: Findings of present study highlights usefulness of the practice of writing generic names in prescriptions. It also raises concern about professional qualification of the chemist who will be decision maker in drug delivery to consumers.
\end{abstract}

Keywords: Attitude, Generic, Janaushadhi, Knowledge, Practice, Prescription

\section{INTRODUCTION}

Generic or non-proprietary name is the name for the active ingredient in the medicine that is decided by an expert committee and is understood internationally. These drugs are usually interchangeable with branded drugs and do not require licence for their manufacturing. Basically, these drugs are marketed after the expiry date of the patent or other exclusive rights. ${ }^{1}$ Writing costly branded names in prescription seldom leads to expensive and unaffordable treatment. ${ }^{2,3}$ Establishment of Pradhan Mantri Bhartiya Janaushadhi Kendras through Pradhan Mantri Bhartiya Janaushadhi Pariyojana (PMBJP) is a breakthrough step to reduce out of pocket expenses in healthcare. ${ }^{4}$ Medical council of India also amended clause 1.5 of the Indian Medical Council (Professional Conduct, Etiquette and Ethics) Regulations, 2002 mandating the doctors to prescribe medicines by generic names in place of brand names. ${ }^{5}$ Prescribing generics whenever the outcome sought is clinical or easily measurable like drugs for pain, 
blood pressure, infections, and so forth will surely reduce treatment cost. While switching to generics may lead to therapeutic failure in drugs requiring careful titration and close tolerances like anticonvulsants, antifungals, thyroid replacement, and others. ${ }^{6}$ Moreover, medical practitioner nowadays have raised concern about education/ qualification of the chemist who is being made the decision maker. This chemist empowerment could increase prices as they may sell brands with higher absolute margins. ${ }^{7}$

With this background, this questionnaire based cross sectional study is designed to assess knowledge, attitude and practice about generic drug names usage in prescription.

\section{METHODS}

This questionnaire based cross sectional observational study was conducted at Department of Pharmacology, Swami Ramanand Teerth Government Rural Medical College, Ambajogai, Maharashtra, India with study objective to assess the existing knowledge, attitude and practices of post graduate students on generic drug names usage in prescription. All the students admitted to post graduation course in academic year 2018 were included in this study. Those who were not willing to give consent were excluded from study. After explaining the benefits and risks of participation in the study to each subject to the fullest extent possible about the study, in language and terms they are able to understand; the investigator obtained written informed consent from all the participants prior to entering the study. All the participant was gathered on the day of data collection. A KAP questionnaire containing 12 questions (knowledge 04, attitude 04, and practice 04) was given to each participant. They were provided 5 minutes to fill the questionnaire. Participants taking extra time were excluded from the study. The participants KAP was assessed by using true/false type and a Likert scale-based question whose responses ranged from "strongly agree "e to "strongly disagree" and "always"e to "never.

Statistical analysis was done using Graph Pad Prism Software Version 6. Simple descriptive statistics were used to generate frequencies, percentages and proportions.

\section{RESULTS}

Total 43 doctors participated in this study. Among them 19 were males and 24 females. The analysis was done using five-point response options of the Likert scale for attitude and practice questionnaire and true or false type options for assessing knowledge.

All participants know that generic drugs are cheaper than branded drugs. Majority, about $72.41 \%$ participants know that generic and branded drugs are equipotent. Surprisingly only $27.59 \%$ participants know about new drug development process and majority $72.41 \%$ failed to answer question about new drug approval correctly. Nearly $86.21 \%$ participants aware about new pharmaceutical policy 2017 (Table 1).

Table 1: Knowledge questionnaire.

\begin{tabular}{|lll|}
\hline Knowledge Questionnaire & True (\%) & False (\%) \\
\hline $\begin{array}{l}\text { Generic drugs are cheaper } \\
\text { than branded drugs. }\end{array}$ & 100 & 0 \\
\hline $\begin{array}{l}\text { Generic drugs are low in } \\
\text { potency and efficacy compared } \\
\text { to branded drugs. }\end{array}$ & 27.59 & 72.41 \\
\hline $\begin{array}{l}\text { Newly approved drugs are } \\
\text { available as branded drugs only. }\end{array}$ & 27.59 & 72.41 \\
\hline $\begin{array}{l}\text { New pharmaceutical policy } \\
\text { 2017 recommends use of e- } \\
\text { prescription for generic drugs. }\end{array}$ & 86.21 & 13.79 \\
\hline
\end{tabular}

Majority (95.02\%) of participants believe that writing generic names in prescription is a good practice and must be made mandatory. Most of them (86.05\%) also believe that this practice will help in establishing a transparent doctor patient relationship.

On the other hand, majority $(65.12 \%)$ were concerned about usefulness and availability of generic drugs in all clinical conditions, while $76.75 \%$ think that writing generic names in prescription will give liberty to pharmacist to select any available brand which will be more profitable for him. About $6.98 \%$ to $13.95 \%$ participants were undecided about their attitude (Table 2).

Table 2: Attitude questionnaire.

\begin{tabular}{|llllll|}
\hline $\begin{array}{l}\text { Practice of writing generic names in } \\
\text { prescription }\end{array}$ & $\begin{array}{l}\text { Strongly agree } \\
(\%)\end{array}$ & $\begin{array}{l}\text { Agree } \\
(\%)\end{array}$ & $\begin{array}{l}\text { Undecided } \\
(\%)\end{array}$ & $\begin{array}{l}\text { Disagree } \\
(\%)\end{array}$ & $\begin{array}{l}\text { Strongly } \\
\text { disagree }(\%)\end{array}$ \\
\hline Is a good practice and must be made mandatory? & 25.58 & 67.44 & 6.98 & 0 & 0 \\
\hline Is impossible in some medical conditions. & 2.33 & 62.79 & 13.95 & 16.28 & 4.65 \\
\hline $\begin{array}{l}\text { Along with generic drug stores will help in } \\
\text { establishing a transparent doctor patient } \\
\text { relationship. }\end{array}$ & 16.28 & 69.77 & 11.63 & 2.33 & 0 \\
\hline $\begin{array}{l}\text { Will provide liberty to pharmacist to supply } \\
\text { from various available brands. }\end{array}$ & 16.28 & 60.47 & 13.95 & 9.3 & 0 \\
\hline
\end{tabular}


In practice questionnaire, majority of the participants shown positive response about consideration of cost before prescribing and allowing patients to choose among various available brands.
Surprisingly large proportion of participants $(90.70 \%)$ rely on promotional literature for knowledge upgradation and don't consider other sources of drug information (Table 3).

Table 3: Practice questionnaire.

\begin{tabular}{|llllll|}
\hline Practice questionnaire & Always (\%) & Usually (\%) & Sometimes (\%) & Seldom (\%) & Never (\%) \\
\hline $\begin{array}{l}\text { Do you consider cost of a drug before } \\
\text { prescribing? }\end{array}$ & 74.42 & 11.63 & 11.63 & 0 & 2.33 \\
\hline $\begin{array}{l}\text { Do you update your knowledge with } \\
\text { promotional literature by a medical } \\
\text { representative? }\end{array}$ & 46.51 & 27.91 & 16.28 & 4.65 & 4.65 \\
\hline $\begin{array}{l}\text { Do you allow patients to choose among } \\
\text { different available brands of a particular } \\
\text { drug? }\end{array}$ & 46.51 & 18.6 & 16.28 & 6.98 & 11.63 \\
\hline $\begin{array}{l}\text { Do you write generic names in your } \\
\text { prescription? }\end{array}$ & 58.14 & 27.91 & 6.98 & 4.65 & 2.33 \\
\hline
\end{tabular}

\section{DISCUSSION}

In the present study, good percentage of participants have considerable knowledge about generic medicines, and they have positive attitude about the safety, efficacy and quality of generic medicines.

Fortunately, the Indian context is better than that noted in other countries. In a study conducted in Auckland, New Zealand, only $51 \%$ of the respondents had heard of the phrase "generic drug." 8 Naing C et al, assessed knowledge of the medications taken by the population of Malaysia, noting that $85.8 \%$ did not know the term "generic drug", $86.3 \%$ did not know how to reply on the quality of generic drugs compared to reference drugs and $86.9 \%$ did not know about price differences between generic and reference drugs. ${ }^{9}$ The good results obtained among the Indian population can be attributed to awareness-heightening and popularization programs for generic drugs, run by the Indian Government and the pharmaceutical companies producing these types of medications. All participants are aware of Jan Aushadhi scheme of Govt. of India whose purpose is to set up generic drug stores around the country which is contrary to the finding of Badwaik $\mathrm{R}$ et al, (Table 1). ${ }^{10}$

High numbers of participants agree that to reduce overall health expenditure generic medicines are an important tool. The cost of generic medicines has been found to be up to $91 \%$ less than that of the innovator medicine in India. ${ }^{11-13}$

In this study, most of the respondents believed in efficacy of generics and being bioequivalent to their innovator counterparts they can be interchangeable with a branded drug. Similar findings were obtained by Thomas R et al, Davit BM et al. and Gupta $\mathrm{S}$ et al. ${ }^{14-16}$
Many participants believe that prescribing generic drugs is impossible in some clinical conditions due to nonavailability or less efficacy (Table 2). However, this effect is not exclusive to generics. This may also be blamed on inter-individual variations, which is a serious problem consisting of a loss of pharmacological efficacy and adverse effects. Some of the factors associated with the variability of the pharmacological and therapeutic effects, are age, pregnancy and the presence of disease. ${ }^{17}$ In fact, there are situations in which a specific medication may present a therapeutic response other than the expected outcome or the patient may even be refractory to pharmacological treatment in some cases. For example, one third of patients with depression are refractory to pharmacological treatment. ${ }^{18}$

In present study, author have found that most of the doctors prescribe generic medicines. These findings are similar to that of Gupta $\mathrm{S}$ et al. ${ }^{16}$ Many admitted that most of the times their prescriptions are influenced by promotional literature and they believe that they prescribe branded drugs which is similar to the finding of another study (Table 3). ${ }^{10}$

Surprisingly only $27.59 \%$ participants know about new drug development process and majority $72.41 \%$ failed to answer question about new drug approval correctly. This finding suggested strong need of knowledge upgradation of health care providers (Table 1).

Small sample size is the major limitations of this study. Thus, findings of this study cannot be generalized. Author have only studied the doctor's perception and understanding regarding generic medicines. It would be appropriate to analyse the perception and understanding of other health care professionals as well as patients. 


\section{CONCLUSION}

In spite of shortcomings the findings of present study cannot be neglected. The data about knowledge, attitude and practice of post graduate resident doctors about writing generic names in prescriptions is generated through this study. Without doubt it highlights usefulness of this practice. It also raises concern about professional qualification of the chemist who will be decision maker in drug delivery to consumers. Study also recommends need of knowledge upgradation of health care providers.

\section{ACKNOWLEDGEMENTS}

Authors would like to thank Dr A. S. Kale sir (Professor and Head, Department of Pharmacology Swami Ramanand Teerth Government Rural Medical College Ambajogai, Maharashtra, India), all staff personnel from Department of Pharmacology and all participants participated for their support during study.

\section{Funding: No funding sources}

Conflict of interest: None declared

Ethical approval: The study was approved by the Institutional Ethics Committee Swami Ramanand Teerth Government Rural Medical College, Ambajogai, Maharashtra, India

\section{REFERENCES}

1. Thakkar K, Billa G. The concept of generic drugs and patented drugs vs. brand name drugs and nonproprietary (generic) name drugs. Frontiers Pharmacol. 2013;12(4):113.

2. Andrade C, Rao TS. Prescription writing: generic or brand?. Ind J Psychiatry. 2017;59(2):133.

3. Flegel K. The adverse effects of brand-name drug prescribing. CMAJ. 2012;184(5):616.

4. Bureau of Pharma PSUs of India (BPPI), Government of India. Available at: http://www.janaushadhi.gov.in/aboutbppi.aspx. Accessed 10 October 2018.

5. Doctors to face action unless they only prescribe generic drugs. MCI India News Times of India. Available at: https://timesofindia.indiatimes.com/india/doctors-toface-action-unless-they-only-prescribe-genericdrugs-mci/articleshow/58314973.cms. Accessed 10 Oct 2018.

6. Kamerow D. The pros and cons of generic drugs. BMJ. 2011;343:d4584.

7. Generic drugs. 73 per cent of doctors oppose push for generic drugs. Study India News Times of India. Available at: https://timesofindia.indiatimes.com/india/73-per- cent-of-doctors-oppose-push-for-generic-drugsstudy/articleshow/58584346.cms. Accessed 10 Oct 2018.

8. Stewart J, Reddy S, Alzaher W, Vareed P, Yacoub N, Dhroptee B, et al. An evaluation of consumers' knowledge, perceptions and attitudes regarding generic medicines in Auckland. Pharm World Sci. 2010;32(4):440-8.

9. Naing C, Kai YC, Yi CH, Yee NS, Yi LM, Jun LX, et al. Knowledge of medication use and factors influencing the utilisation of public health clinics. Int Heal. 2013;5(3):217-22.

10. Badwaik RT, Chopade SS, Mahajan HM, Honrao R. Prescribers views on generic medicines: A study on knowledge, attitude and practice. J Cont Med A Dent. 2015;3(2):27-32.

11. Singal GL, Nanda A, Kotwani A. A comparative evaluation of price and quality of some branded versus branded-generic medicines of the same manufacturer in India. Ind J Pharmacol. 2011;43(2):131.

12. Mathew P. Generic drugs: Review and experiences from South India. J Family Med Primary Care. 2015;4(3):319.

13. Lopes GD. Cost comparison and economic implications of commonly used originator and generic chemotherapy drugs in India. Ann Oncol. 2013;24(5):v13-6.

14. Thomas R, Vitry A. Consumer's perception of generic medicines in community pharmacies in Malaysia. Southern Med Rev. 2009;2(2).

15. Davit BM, Nwakama PE, Buehler GJ, Conner DP, Haidar SH, Patel DT, et al. Comparing generic and innovator drugs: a review of 12 years of bioequivalence data from the United States Food and Drug Administration. Ann Pharmacotherapy. 2009;43(10):1583-97.

16. Gupta SK, Nayak RP, Vidyarthi SK. A study on the knowledge, attitude, and practice of generic medicines among the doctors in a tertiary care teaching hospital in South India. National J Physiol Pharm Pharmacol. 2015;5(1):39.

17. Ritter J, Flower RJ, Rod J, Henderson G, Loke YK, MacEwan DJ, Rang HP. Rang and Dale's Pharmacology. 9th ed. London: Elsevier; 2019:808.

18. Stahl SM. Stahl's Essential Psychopharmacology Neuroscientific Basis and Third Edition. 3rd ed. Newyork: Cambridge University Press; 2008.

Cite this article as: Jadhav RR, Kulkarni RS, Rathod AV. Knowledge, attitude and practices of generic names usage in prescription among the medical postgraduate residents of a tertiary care teaching hospital: an observational cross-sectional study. Int J Basic Clin Pharmacol 2019;8:1030-3. 